\title{
Оценка состояния ценопопуляций Cypripedium guttatum Sw. на хребте Ивановском Казахстанского Алтая
}

\section{Assessment of the state of coenopopulations Cypripedium guttatum Sw. on the Ivanovsky Ridge in the Kazakhstan Altai}

\author{
Данилова А. Н., Котухов Ю. А., Ануфриева О. А., Сумбембаев А. А. \\ Danilova A. N., Kotuchov Yu. A., Anufrieva O. A., Sumbembaev A. A. \\ Алтайский ботанический сад, г. Риддер, Казахстан. E-mail: a-n-danilova@yandex.ru \\ Altai Botanical Garden, Ridder, Kazakhstan
}

\begin{abstract}
Peфepam. В данной статье приводятся результаты исследования на северо-западном склоне хр. Ивановский трех ценопопуляций Cypripedium guttatum: чернично-осокового, душистоколосково-башмачкового, фиалково-чернично-осокового фитоценозов. Установлено, что во всех ценопопуляциях Cypripedium guttatum выступает как активно действующий вид, способный удерживать занятую территорию. Самоподдержание и возобновление вида происходит за счет вегетативного размножения. По возрастной структуре ценопопуляции нормального типа, левосторонние, неполночленные.
\end{abstract}

Ключевые слова. Особь, плотность, фитоценоз, хребет Ивановский, ценопопуляция, Cypripedium guttatum.

Summary. This article presents the results of a study of threee coenopopulations of Cypripedium guttatum on the north-western slope of the ridge Ivanovsky: bilberry-sedge, Anthoxanthum odoratum-Cypripedium, violet-bilberry-sedge phytocenoses. It has been established that in all cenopopulations Cypripedium guttatum play an active role as a species capable to hold an occupied territory. Self-maintenance and renewal of the species occurs due to vegetative reproduction. According to the age structure, coenopopulations are normal, left-sided, incomplete.

Key words. Coenopopulation, Cypripedium guttatum, density, individual, Ivanovsky Ridge, phytocenosis.

Представители семейства орхидные являются наиболее уязвимыми видами любой флоры. Особенности биологии и высокая чувствительность видов к антропогенным воздействиям препятствуют их широкому распространению. Из 27 видов орхидных, произрастающих в Казахстане, во флоре Казахстанского Алтая насчитывается 23 вида, из них 7 видов занесены в Красную книгу Казахстана (Флора Казахстана, 1958; Котухов, 2005; Красная книга Казахстана, 2014). Отсюда весьма актуальным является изучение экологии, биологии охраняемых видов, состояния их популяций в естественных условиях, в частности, Cypripedium guttatum S w. - редкого вида флоры Казахстана.

Cypripedium guttatum $\mathrm{S}$ w. - евроазиатский бореальный вид, встречается на северо-востоке и в центре лесной зоны европейской части бывшего СССР (преимущественно в восточных районах), в Западной и Восточной Сибири, на Дальнем Востоке, а также в Монголии, Китае, Японии (Иванова, 1987). В Казахстане Cypripedium guttatum Sw. отмечен на севере Петропавловской области (Байтенов, 1985); на Алтае: хр. Убинский, окр. г. Риддер; дол. р. Иртыш, северо-западнее г. Семипалатинска; около г. Усть-Каменогорска (Крылов, 1929); хр. Ивановский (Котухов и др., 2009).

В рамках выполнения грантового проекта АР05133868 «Изучение распространения и современного состояния популяций видов семейства Орхидных Казахстанского Алтая и их интродукция в Алтайском ботаническом саду" работы по оценке состояния ценопопуляций Cypripedium guttatum проведены на северо-западном склоне хр. Ивановский, простирающегося с юго-запада на юго-восток Юго-Западного Алтая в горной системе Казахстанского Алтая. Климат района исследований резко кон- 
тинентальный. Многолетняя средняя температура июля $+18+22^{\circ} \mathrm{C}$, января $-18-22^{\circ} \mathrm{C}$. Среднегодовое количество осадков варьирует от 400 до 1500 мм в год. (Егорина и др., 2003).

Исследованы три пространственно-изолированные ценопопуляции, в которых закладывали учетные площадки размером $1 \mathrm{~m}^{2}$. В работе использовали общепринятые популяционно-биологические методы исследований редких видов растений, включающие эколого-фитоценотические показатели, возрастной состав, жизненность вида (Быков,1957; Денисова и др., 1986). Определение видового состава растений в фитоценозах с участием орхидных проведено по академическому изданию «Флора Казахстана» (1956-1966).

Ценопопуляция чернично-осокового (Carex macroura Meinsh., Vaccinium myrtillus L.) фитоцено-

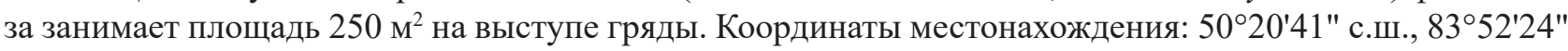
в.д., 1407 м над ур. м. Рельеф участка выровненный, мелко-бугристый. Почвенный слой - горный чернозем, рыхлый до 45 см. Гумусный горизонт имеет мощность около 25 см., умеренно увлажненный.

Ценопопуляция входит в состав тонкомерного лиственничного леса с сомкнутостью крон древостоя 04-05, который защищает Cypripedium guttatum от интенсивной инсоляции. Местами отмечаются единичные деревья Betula pendula Roth. Подлесок редкий из Sorbus sibirica Hedl., кустарниковый ярус образован Spiraea media Franz Schmidt, Cotoneaster uniflorus Bunge, Rosa acicularis Lindl., с покрытием 1,5-3,0 \%. Травянистый покров хорошо сформирован, с общим покрытием до 85 \%, в котором доминантами выступают Carex macroura Meinsh. и Vaccinium myrtillus L. На их долю в покрытии приходится 35 \%. В формировании травостоя также участвуют Cypripedium guttatum, Calamagrostis obtusata Trin., Trollius altaicus C. A. Mey., Aquilegia glandulosa Fisch. ex Link., Vicia megalotropis Ledeb., Euphorbia pilosa L., Aegopodium alpestre Ledeb., Galium boreale L., Veratrum lobelianum Bernh, Iris ruthenica Ker-Gawl., Allium microdictyon Prokh. Моховой покров слабо выражен.

Cypripedium guttatum по площади размещен рассеянно в виде отдельных многопобеговых дернин или небольших клоновых куртин, диаметром от 39 до 45 см. Демографическая структура ценопопуляции неполночленная, левосторонняя, так как сформирована из 11 генеративных, 17 виргинильных, 4 имматурных особей. Проростки, ювенильные и сенильные особи не выявлены. Отсутствие проростков и ювенильных растений указывает на слабое семенное размножение или его отсутствие. Следует отметить, что особи с семенными коробочками в период описания в ценопопуляции не были обнаружены. Самоподдержание вида в ценопопуляции происходит вегетативном способом за счет распада крупных дернин на отдельные клоновые особи. В количественном соотношении средняя плотность побегов на 1 м $^{2}$ составила 44,9, в том числе генеративных- 23,4, вегетативных - 66,5, что свидетельствует об активной жизненности вида в ценопопуляции.

Ценопопуляция душистоколосково-башмачкового (Cypripedium guttatum Sw., Anthoxanthum odoratum L.) фитоценоза занимает поляну, со всех сторон окруженную парковым лиственничником (Larix sibirca Ledeb.) с незначительной примесью Betula pendula. Подлесок слабо развит, представлен Sorbus sibirica, Rosa acicularis, R. pimpinellifolia L., Cotoneaster uniflorus Bunge. Координаты местонахождения: 50²1'14" с.ш., 8353'34" в.д., 1400 м над ур. м. Участок продолговато вытянут поперек склона; хорошо освещен, защищен от господствующих ветров. Почвы рыхлые, богато гумусированные, со значительной примесью крупнозернистого микрозема, умеренно увлажненные. Подстилающий слой сильно разрушенная материнская порода.

Фитоценоз - низкотравное сообщество с проективным покрытием 50-60 \%. Его структуру и облик определяют доминирование Anthoxanthum odoratum и Cypripedium guttatum, на долю которых в проективном покрытии приходится 25-30 \%. Травостой нечетко двухъярусный, представлен всего 6 видами. Первый ярус, 50-60 см высоты, образован одним видом - Calamagrostis obtusata, сомкнутость не более $0,1 \%$. Второй ярус сложен плотнодерновинными горно-степными видами: Iris ruthenica, Carex macroura, Gentiana decumbens L. и луговыми Anthoxanthum odoratum L., Cypripedium guttatum, с общим покрытием 60 \%. Напочвенный моховой покров отсутствует, в плотном травостое отмечается незначительное накопление опада.

Cypripedium guttatum произрастает на поляне рассеянно, отдельными особями, рыхлыми группами, реже, клональными куртинами, где занимает позиции активно действующего вида с проектив-

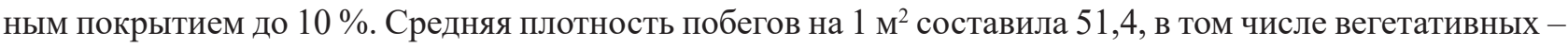


75,2, генеративных - 27,6 шт. В возрастном спектре в пересчете на 1 м² преобладают вегетативные особи, в процентном соотношении доля которых составляет $72,42 \%$, генеративных соответственно 27,58 \%. Преобладание вегетативных особей, по-видимому, является результатом накопления временно нецветущих генеративных экземпляров, возникших в результате клонального распада стареющих генеративных особей. Ювенильные и имматурные особи не обнаружены, что может свидетельствовать о низкой выживаемости растений на ранних стадиях развития из-за отсутствия мохового покрова, слабо развитого опада, непостоянной влажности почвы, высокой инсоляции. Отсутствие в демографической структуре ювенильных, имматурных и сенильных особей свидетельствует, что ценопопуляция левосторонняя, неполночленная, самоподдержание которой происходит вегетативным способом, так как образование семенных коробочек не выявлено.

Ценопопуляция фиалково-чернично-осокового (Carex macroura Meinsh., Vaccinium myrtillus L., Viola uniflora L.) фитоценоза расположена на поляне, окруженной березово-лиственничным лесом (Larix sibirca Ledeb., Betula pendula Roth), с подлеском из Rosa acicularis, Spiraea media, Cotoneaster uniflorus. Координаты местонахождения: 50²1'14" с.ш., 8353'34" в.Д.,1450 м над ур. м. Поляна хорошо освещена и прогреваема. Почвенный слой неоднородный, от 27 до 45 см. Подстилающий слой составлен обломками породы и мелкого щебня вперемешку с глиной. Травостой представлен 5-6 видами с общим проективным покрытием 70-75\%, где доминантами выступают Carex macroura, Viola uniflora, Vaccinium myrtillus, на долю которых в покрытии приходится до 75 \%. Из сопутствующих видов обычны $A e-$ gopodium alpestre Ledeb., Galium krylowianum (Serg.) Pobed., Iris ruthenica, Bistorta major S. F. Gray.

Cypripedium guttatum по площади распределен рассеянно, многопобеговыми особями. Средняя плотность составила 40,0 побегов на 1 м²$^{2}$ в том числе: вегетативных - 54,3, генеративных - 25,7, что свидетельствует об активной жизненности вида в ценопопуляции. В возрастном спектре выявлены ювенильные (9,8 \%), разновозрастные вегетативные (48,6 \%) и генеративные особи (41,6 \%). Ценопопуляция нормального типа, левосторонняя, неполночленная, возобновление которой происходит в основном вегетативно и незначительно семенным путем.

Анализ полученных результатов показал, что фитоценотический комплекс в обследованных ценопопуляциях достаточно постоянный, состоит из 5-16 видов. Почвенный горизонт всех местообитаний характеризуется богатым содержанием первичного гумуса, рыхлостью и постоянством умеренного увлажнения. Cypripedium guttatum в ценопопуляциях выступает как активно действующий вид, способный удержать занятую территорию за счет активного вегетативного возобновления. Реализуется также семенной способ размножения, нерегулярно и очень ограниченно. Все обследованные ценопопуляции по характеру строения левосторонние, неполночленные, нормального типа, с доминированием виргинильных особей.

\section{ЛИТЕРАТУРА}

Байтенов М. С. В мире редких растений. - Алма-Ата: Кайнар,1985. - 176 с.

Быков Б. А. Геоботаника. - Алма-Ата: Изд-во АН Каз.ССР, 1957. - 381 с.

Денисова Л. В., Никитина С. В., Заугольнова Л. Б. Программа и методика наблюдений за ценопопуляциями видов Красной книги СССР. - М.: Госагропром, 1986. - 125 с.

Егорина А. В., Зинченко Ю. К., Зинченко Е. С. Физическая география Восточного Казахстана. - Усть-Каменогорск: Альфа-Пресс, 2003. - 187 с.

Иванова Е. В. Семейство Orchidaceae- Ятрышниковые, или орхидные //Флора Сибири. - Новосибирск: Наука, 1987. - С. $125-145$.

Котухов Ю. $\boldsymbol{A}$. Список сосудистых растений Казахстанского Алтая //Ботанические исследования Сибири и Казахстана, 2005. - С. 11-83.

Котухов Ю. А., Данилова А. Н., Ануфриева О. А. Современное состояние популяций редких и исчезающих растений Восточного Казахстана. - Алматы: Тетис, 2009. - 140 с.

Красная книга Казахстана. Т. 2. Ч. 1. Растения. - Астана, 2014. - 448 с.

Крылов П. Н. Флора Западной Сибири. - Томск: Изд-е Томского Отд. Русск. Ботан. общ-ва, 1929. - Вып. III. - C. $378-718$.

Флора Казахстана. - Алма-Ата: Изд-во АН Каз. ССР, 1958 - 1966.

Флора Казахстана. - Алма-Ата: Изд-во АН Каз. ССР, 1958. - Т. 2. - 290 с. 